\title{
A.N.Narkevich, N.M.Koretskaya, K.A.Vinogradov, A.A.Narkevich Influence of age, gender and social factors on risk of occurrence of pulmonary tuberculosis
}

\begin{abstract}
Summary
A contribution of age, gender and social factors to probability of pulmonary tuberculosis occurrence in various cohorts of population was analyzed. On the basis of the obtained data, a computer system was developed to define a total individual risk of pulmonary tuberculosis occurrence. This approach could allow estimation of rate of preventive fluorographic investigation in different population cohorts.

Key words: pulmonary tuberculosis, detection, risk factors, social factors.
\end{abstract}

\section{Резюме}

Была проанализирована значимость возраста, пола, социальных факторов на вероятность выявления туберкулеза легких у различных категорий населения. Полученные данные включены в разрабатываемую компьютерную систему, определяющую суммарный индивидуальный риск выявления туберкулеза легких, что позволит научно обосновать кратность прохождения проверочного флюорографического обследования различными категориями населения.

Ключевые слова: туберкулез легких, выявление, факторы риска, социальный статус.

В последнее время широкое научное признание получил селективный подход к выявлению больных туберкулезом легких, заключающийся в отличии кратности прохождения профилактического флюорографического обследования лицами различных категорий населения, установленной на основании индивидуальных особенностей обследуемых [1, 2].

Важную роль в формировании и реализации селективного подхода к организации выявления туберкулеза легких среди населения занимает научно обоснованная разработка критериев включения различных категорий в группы повышенного риска [3-5], среди которых важнейшей является принадлежность к одной из социальных категорий [6-8].

Целью данного исследования явился анализ значимости возраста, пола, социальных факторов на риск выявления туберкулеза легких среди различных категорий населения.

\section{Материалы и методы}

Для определения факторов риска выявления туберкулеза легких среди населения была разработана анкета, включающая данные о возрастной, половой принадлежности, социальном статусе, семейном положении и уровне образования.

В опросе участвовали больные впервые выявленным туберкулезом легких $(n=342)$, лечившиеся в стационарах Красноярских краевых противотуберкулезных диспансеров № 1 и 2 (1-я группа - основная), и здоровые лица $(n=386)$, проходившие проверочное флюорографическое обследование в поликлиниках
Красноярска и Красноярского края (2-я группа контрольная). Здесь и далее под "здоровыми" подразумеваются лица, у которых по результатам флюорографического обследования не выявлено изменений в легких, связанных с туберкулезным процессом. Анкетирование проводилось в 2013 г. Исследование соответствовало этическим стандартам биоэтического комитета Красноярского государственного медицинского университета им. проф. В.Ф.Войно-Ясенецкого, разработанным в соответствии с Хельсинкской декларацией Всемирной ассоциации "Этические принципы проведения научных медицинский исследований с участием человека" с поправками 2000 г. и "Правилами клинической практики в Российской Федерации", утвержденными Приказом Минздрава РФ от 19.06.03 № 266. У всех лиц, участвующих в исследовании, получено информированное согласие.

Для определения подчинения закону нормального распределения количественных данных использовался критерий Шапиро-Уилка [9]; при уровне значимости $p<0,05$ гипотеза о нормальности распределения отвергалась, т. к. все количественные данные, полученные в результате исследования, не подчинялись закону нормального распределения, они представлены в виде медианы - Me $(L ; U)$ и 95\%-ного доверительного интервала (ДИ), где $L-$ нижняя граница ДИ, $U-$ верхняя граница ДИ. Для долей 95\%-ного ДИ рассчитывался по методу Вальда-Вольфовица [10].

Различия между качественными (номинальными) признаками оценивались с помощью критерия 
$\chi^{2}$ (результаты представлены в виде: $\chi^{2}-$ значение критерия, $d f-$ число степеней свободы) [11]. Для оценки влияния изучаемых факторов на индивидуальный риск выявления туберкулеза легких рассчитывался показатель отношения рисков - ОР (представлен в виде ОР и 95\%-ного ДИ) [12]. Нулевая гипотеза об отсутствии статистически значимых различий отвергалась при $p<0,05$.

\section{Результаты и обсуждение}

В обеих группах преобладали сельские жители $(65,2 \pm$ $3,46 \%$ ), но по сравнению с 1-й группой, во 2-й их удельный вес был значительно выше: 72,50 \pm 4,45 \% чески значимо $\left(\chi^{2}=19,3 ; d f=1 ; p<0,001\right)$. Следовательно, фактором риска выявления туберкулеза является проживание в городе, причем данный фактор повышает этот риск почти в 1,5 раза: $\mathrm{OP}=1,4$ $(1,21 ; 1,64)$.

Среди лиц 1-й группы несколько выше удельный вес мужчин $(56,4 \pm 5,26 \%)$, а среди лиц 2-й группы женщин $(54,7 \pm 4,97 \%)$, т. е. мужчины болели туберкулезом статистически значимо чаще $\left(\chi^{2}=8,9 ; d f=1\right.$; $p=0,004)$, несмотря на довольно небольшой риск выявления у них данного заболевания: ОР = 1,2 (1,08; $1,48)$.

При анализе возрастной структуры лиц обеих групп (табл. 1) были выявлены некоторые особенности $\left(\chi^{2}=42,6 ; d f=6 ; p<0,001\right)$.

Среди впервые выявленных больных туберкулезом легких, чаще, чем среди здоровых, встречались лица в возрасте 30-39 и 40-49 лет $(29,2 \pm 4,82 \%$ и $21,1 \pm 4,32 \%$ соответственно), реже - лица стар-

Таблица 1

Возрастная структура лищ, исследуемых групп

\begin{tabular}{|l|c|c|}
\hline Возраст, годы & 1 -я группа & 1 -я группа \\
\hline $18-19$ & $16(4,70 \pm 2,24)$ & $15(3,90 \pm 1,93)$ \\
\hline $20-29$ & $75(21,90 \pm 4,38)$ & $81(21,00 \pm 4,06)$ \\
\hline $30-39$ & $100(29,20 \pm 4,82)$ & $73(18,90 \pm 3,91)$ \\
\hline $40-49$ & $72(21,10 \pm 4,32)$ & $60(15,50 \pm 3,61)$ \\
\hline $50-59$ & $55(16,1 \pm 3,9)$ & $69(17,90 \pm 3,82)$ \\
\hline $60-69$ & $16(4,70 \pm 2,24)$ & $44(11,40 \pm 3,17)$ \\
\hline$>70$ & $8(2,30 \pm 1,59)$ & $44(11,40 \pm 3,17)$ \\
\hline
\end{tabular}

Примечание: здесь и в табл. 2-4: значения выражены в $n(\%) \pm 95 \%$-ный ДИ. и 57,00 $\pm 5,25 \%$ соответственно; различие статисти-

ших возрастных групп (60-69 лет и старше 70 лет). Так, удельный вес лиц старших возрастных групп среди впервые выявленных больных туберкулезом легких составил 4,7 $\pm 2,24$ и 2,3 $\pm 1,59 \%$ vs $11,4 \pm 3,17$ и $11,4 \pm 3,17 \%$ соответственно среди здоровых, т. е. группа больных туберкулезом легких состояла преимущественно из населения наиболее экономически активного возраста.

Эти данные подтверждаются и результатами анализа социальной структуры лиц, входящих в состав исследуемых групп $\left(\chi^{2}=116,4 ; d f=5 ; p<0,001\right)$, представленными в табл. 2.

По сравнению со 2-й группой, в 1-й чаще встречались лица рабочих профессий $(24,30 \pm 4,55 \%$ vs $15,80 \pm 3,46 \%)$ и реже - пенсионеры $(7,60 \pm 2,81 \%$ vs $24,10 \pm 4,27 \%$ ). Установлено, что у неработающих лиц трудоспособного возраста ОР выявления туберкулеза легких выше практически в 2 раза, чем у остального населения $(\mathrm{OP}=1,9(1,62 ; 2,16) ; p<0,001)$, а у служащих и пенсионеров, наоборот, ниже в $>2$ раза $(\mathrm{OP}=0,4(0,28 ; 0,57) ; p<0,001$ и $\mathrm{OP}=0,5(0,34$; $0,69) ; p<0,001$ соответственно). У медицинских работников и индивидуальных предпринимателей риск выявления туберкулеза легких статистически значимо не отличался от остального населения $(\mathrm{OP}=1,1(0,70 ; 1,83) ; p=0,605$ и $1,1(0,63 ; 1,81)$; $p=0,814$ соответственно).

Анализ образовательного уровня $\left(\chi^{2}=101,5 ; d f=5\right.$; $p<0,001)$ показал, что туберкулезом легких чаще болеют лица, имеющие среднее и среднее профессиональное образование $(30,40 \pm 4,89 \%$ и $22,80 \pm 4,45 \%$ соответственно), табл. 3 .

Во 2-й группе чаще, чем в 1-й, встречались лица, имеющие среднее специальное, незаконченное высшее и высшее образование $(22,50 \pm 4,15 \%, 5,90 \pm$ $2,35 \%$ и $31,60 \pm 4,64 \%$ vs $20,20 \pm 4,26 \%, 2,30 \pm 1,59 \%$ и 5,80 $\pm 2,48 \%$ соответственно). Следовательно, у лиц, имеющих среднее и среднее профессиональное образование, риск выявления туберкулеза легких выше, чем у остальных (OP $=1,5(1,29 ; 1,74)$; $p<0,001$ и ОР $=1,3(1,14 ; 1,59) ; p<0,001$ соответственно). У лиц, имеющих высшее образование, напротив, данный риск минимален $(\mathrm{OP}=0,3(0,17$; $0,38) ; p<0,001)$.

По данным исследования, для развития туберкулеза немаловажно и семейное положение: так, в 1-й группе 54,70 $\pm 5,28 \%$ лиц не состоят ни в зарегистрированном, ни в гражданском браке, в то время как

Таблица 2 Социальная структура лиц, исследуемых групп

\begin{tabular}{|c|c|c|c|c|}
\hline Социальная группа & 1-я группа & 2-я группа & OP & $p$ \\
\hline Учащиеся & $9(2,60 \pm 1,69)$ & $17(4,40 \pm 2,05)$ & $0,7(0,42 ; 1,24)$ & 0,247 \\
\hline Рабочие & $83(24,30 \pm 4,55)$ & $61(15,80 \pm 3,46)$ & $1,2(0,93 ; 1,29)$ & 0,240 \\
\hline Служащие & $26(7,60 \pm 2,81)$ & $98(25,40 \pm 4,34)$ & $0,4(0,28 ; 0,57)$ & $<0,001$ \\
\hline Пенсионеры & $26(7,60 \pm 2,81)$ & $93(24,10 \pm 4,27)$ & $0,5(0,34 ; 0,69)$ & $<0,001$ \\
\hline Инвалиды & $17(5,00 \pm 2,31)$ & $25(6,50 \pm 2,46)$ & $0,9(0,59 ; 1,24)$ & 0,411 \\
\hline Неработающие лица трудоспособного возраста & $66(48,50 \pm 5,30)$ & $84(22,20 \pm 4,01)$ & $1,9(1,62 ; 2,16)$ & $<0,001$ \\
\hline Медицинские работники & $8(2,30 \pm 1,59)$ & $7(1,80 \pm 1,33)$ & $1,1(0,70 ; 1,83)$ & 0,605 \\
\hline Индивидуальные предприниматели & $7(2,00 \pm 1,48)$ & $1(0,30 \pm 0,30)$ & $1,1(0,63 ; 1,81)$ & 0,814 \\
\hline
\end{tabular}


Образовательный уровень лиц исследуемых групп

\begin{tabular}{|c|c|c|c|c|}
\hline Образовательный уровень & 1-я группа & 2-я группа & OP & $p$ \\
\hline Основное общее & $63(18,40 \pm 4,11)$ & $41(10,60 \pm 3,07)$ & $1,1(0,95 ; 1,34)$ & 0,167 \\
\hline Среднее & $104(30,40 \pm 4,89)$ & $60(15,50 \pm 3,61)$ & $1,5(1,29 ; 1,74)$ & $<0,001$ \\
\hline Среднее профессиональное & $78(22,80 \pm 4,45)$ & $53(13,70 \pm 3,43)$ & $1,3(1,14 ; 1,59)$ & $<0,001$ \\
\hline Среднее специальное & $69(20,20 \pm 4,26)$ & $87(22,50 \pm 4,15)$ & $0,9(0,76 ; 1,12)$ & 0,447 \\
\hline Незаконченное высшее & $8(2,30 \pm 1,59)$ & $23(5,90 \pm 2,35)$ & $0,5(0,29 ; 0,98)$ & 0,044 \\
\hline Высшее & $20(5,80 \pm 2,48)$ & $122(31,60 \pm 4,64)$ & $0,3(0,17 ; 0,38)$ & $<0,001$ \\
\hline
\end{tabular}

Таблица 4

Семейное положение лии, исследуемых групп

\begin{tabular}{|l|c|c|c|}
\multicolumn{1}{c|}{ Семейное положение } & 1-я группа & 2-я группа & OP \\
Не состоят в браке & $118(34,5 \pm 5,04)$ & $86(22,3 \pm 4,15)$ & $1,4(1,16 ; 1,58)$ \\
\hline Состоят в браке & $21(35,3 \pm 5,07)$ & $206(53,4 \pm 4,98)$ & $0,7(0,57 ; 0,79)$ \\
Разведены & $39(11,4 \pm 3,370$ & $22(5,7 \pm 2,31)$ & $1,4(1,16 ; 1,76)$ \\
Вдовы / вдовцы & $30(8,8 \pm 3,00)$ & $50(13,0 \pm 3,36)$ & $0,8(0,58 ; 1,05)$ \\
\hline Состоят в гражданском браке & $34(9,9 \pm 3,17)$ & $22(5,7 \pm 2,31)$ & $1,3(1,07 ; 1,69)$
\end{tabular}

среди обследуемых 2-й группы таковых было только $40,90 \pm 4,90 \%\left(\chi^{2}=13,1 ; d f=1 ; p<0,001\right)$. При выявлении туберкулеза у лиц, не состоящих ни в зарегистрированном, ни гражданском браке, ОР $=1,3$ $(1,14 ; 1,56) ; p<0,001$.

По данным анализа семейного положения (табл. 4) лиц 1-й и 2-й групп $\left(\chi^{2}=35,9 ; d f=4 ; p<0,001\right)$, не состоящих в браке и разведенных, риск выявления туберкулеза легких выше $(\mathrm{OP}=1,4(1,16 ; 1,58) ; p<0,001$ и ОР $=1,4(1,16 ; 1,76) ; p<0,001$ соответственно).

Риск выявления туберкулеза легких также выше у лиц, проживающих в гражданском браке $(\mathrm{OP}=1,3$ $(1,07 ; 1,69) ; p=0,010)$. У лиц, состоящих в зарегистрированном браке, напротив, риск выявления туберкулеза легких ниже, чем у остальных $(\mathrm{OP}=0,7$ $(0,57 ; 0,79) ; p<0,001)$.

\section{Заключение}

Таким образом, наибольшее влияние на риск выявления туберкулеза легких оказывает отсутствие работы и семьи, низкий образовательный уровень и проживание в городе; значимость же влияния возраста, профессии несколько ниже. Степень риска каждого из перечисленных факторов необходимо учитывать при разработке селективного подхода к организации выявления туберкулеза среди населения наряду с медико-биологическими и эпидемиологическими факторами риска.

Полученные данные включены в разрабатываемую компьютерную систему, позволяющую определить суммарный индивидуальный риск выявления туберкулеза легких с последующим определением кратности прохождения проверочного флюорографического обследования лицами, принадлежащими к различным категориям населения Красноярского края.

\section{Литература}

1. Богородская Е.М., Смердин С.В., Стерликов С.В. и др. Возможности повышения качества проведения профи- лактических осмотров населения на туберкулез. Менеджмент качества в сфере здравоохр. и соц. развития 2012; $1: 34-38$.

2. Иванова О.Г., Мордык А.В., Пузырева Л.В. и др. Эффективность мероприятий по выявлению туберкулеза органов дыхания в Омской области. Кубан. науч. мед. вестн. 2011; 4: 102-104.

3. Баласанани Г.С., Федоров С.В., Скрынник Н.А. Эффективность основных методов выявления туберкулеза среди взрослого населения. В кн.: Туберкулез в России. Год 2007: Материалы VIII Российского съезда фтизиатров. М.; 2007; 145.

4. Горбунов А.В. Организация раннего выявления больных туберкулезом в городе Москве. В кн.: Туберкулез в России. Год 2007: Материалы VIII Российского съезда фтизиатров. М.; 2007; 150.

5. Коломиеи В.М., Петрухина Л.Н., Рублева Н.В. Эффективность массовых проверочных осмотров населения на туберкулез в сельской местности. В кн.: Торакальная радиология: Силлабус Международной конференции и школы для врачей. СПб.; 2010; 208-209.

6. Гурьянов В.Н., Рогожина Н.А., Гладышева И.Г. Социальный паспорт больных туберкулезом легких в Республике Мордовия. В кн.: Туберкулез сегодня. Год 2003: Материалы VII Российского съезда фтизиатров. М.; 2003; 12.

7. Рашкевич Е.Е., Мякишева Т.В., Авдеева Т.Г. Социальные факторы риска и их влияние на характер и течение туберкулеза у подростков. Сиб. мед. обозр. 2011; 6: 97-99.

8. Harstad I., Jacobsen G.W., Heldal E. et al. The role of entry screening in case finding of tuberculosis among asylum seekers in Norway. BMC Publ. Hlth 2010; 10: 670.

9. Shapiro S.S., Wilk M.B. An analysis of variance test to normality (complete samples). Biometrika 1965; 52 (3-4): 591-611.

10. Wald A., Wolfovitz J. Confidence limits for continuous distribution functions. Ann. Mathemat. Stat. 1939. 10: $105-118$.

11. Глани С. Медико-биологическая статистика: Пер. с англ. М.: Практика; 1998.

12. Бабич П.Н., Чубенко А.В., Лапач С.Н. Применение современных статистических методов в практике клинических исследований. Сообщение 3 -е. Отношение 
шансов: понятие, вычисление и интерпретация. Укр. мед. часопис 2006; 2: 113-119.

\section{Информация об авторах}

Наркевич Артем Николаевич - аспирант кафедры медицинской кибернетики ГБОУ ВПО "Красноярский государственный медицинский университет им. проф. В.Ф.Войно-Ясенецкого"; тел.: (391) 220-03-89; e-mail: narkevichart@gmail.com

Корецкая Наталия Михайловна - д. м. н., проф., заведующий кафедрой туберкулеза с курсом ПО ГБОУ ВПО "Красноярский государственный медицинский университет им. проф. В.Ф.Войно-Ясенецкого"; тел.: (391) 261-76-82; e-mail: kras-kaftuber@mail.ru
Виноградов Константин Анатольевич - д. м. н., проф., заведующий кафедрой медицинской кибернетики ГБОУ ВПО "Красноярский государственный медицинский университет им. проф. В.Ф.Войно-Ясенецкого"; тел.: (391) 220-03-89; e-mail: vinogradov16@yandex.ru

Наркевич Анна Александровна - ассистент кафедры туберкулеза Наркеви Анна ( университет им. проФ. В.Ф.Войно-Ясенецкого"; тел.: (391) 261-76-82; e-mail: kras-kaftuber@mail.ru

Поступила 10.06.13

сКоллектив авторов удк 616.24-002.5-053 